\title{
IDENTIFICATION OF DRUG-RELATED PROBLEMS IN ADULTS WITH TUBERCULOSIS AT THE TEBET SUBDISTRICT HEALTH CENTER FROM JULY TO DECEMBER 2018
}

\author{
ATIKA WAHYU PUSPITASARI ${ }^{1 *}$, SAVIRA RAHMAWATI YUNAZ ${ }^{1}$, LINA NADHILAH ${ }^{2}$ \\ ${ }^{1}$ Clinical Pharmacy Laboratory, Faculty of Pharmacy, Universitas Indonesia, Depok, Indonesia. ${ }^{2}$ Tebet Subdistrict Health Center, Jakarta, \\ Indonesia. Email: atikawp.mi@gmail.com
}

Received: 26 September 2019, Revised and Accepted: 17 December 2019

\section{ABSTRACT}

Objective: Tuberculosis (TB) is a highly prevalent infectious disease caused by Mycobacterium tuberculosis. The recommended TB treatment is a combination of various antibiotics in the form of a fixed-dose combination tablet or kombipak; however, this increases the prevalence of drug-related problems. Therefore, this study aimed to identify drug-related problems of patients receiving TB therapy at the Tebet Subdistrict Health Center from July 2018 to December 2018.

Methods: The study was designed as a cross-sectional study using the retrospective data retrieval method from prescriptions of patients with TB from July 2018 to December 2018. The classification system prepared by Cipolle, Strand, and Morley was used for the classification of drugrelated problems; this system includes unnecessary drug therapy, required additional drug therapy, ineffective drug, dosage error, and drug interaction.

Results: The percentage of unnecessary drug therapy, required additional drug therapy, ineffective drug, dosage error, and drug interaction was $2.85 \%, 6.89 \%, 1.54 \%, 12.46 \%$, and $66.18 \%$, respectively, with the occurrence of drug-related problems being the highest.

Conclusion: The administration of anti-TB drugs can potentially cause drug-related problems. Therefore, the assessment needs to be optimized before the administration of medications to patients and medications should be prescribed and monitored regularly to achieve rational drug use.

Keywords: Tuberculosis, Mycobacterium tuberculosis, Antituberculosis, Drug-related problems, Cipolle.

(C) 2020 The Authors. Published by Innovare Academic Sciences Pvt Ltd. This is an open access article under the CC BY license (http://creativecommons. org/licenses/by/4. 0/) DOI: http://dx.doi.org/10.22159/ijap.2020.v12s1.FF010

\section{INTRODUCTION}

Tuberculosis (TB) is a highly prevalent communicable disease caused by Mycobacterium tuberculosis [1]. The World Health Organization [2] stated that 9 million individuals were infected by $M$. tuberculosis in 2013 worldwide. Moreover, 1.5 million individuals worldwide die due to $M$. tuberculosis infection annually. In 2017, $87 \%$ of new TB cases occurred in 30 countries and $>95 \%$ cases of TB-infected individuals in developing countries such as India, China, Indonesia, the Philippines, Pakistan, Nigeria, Bangladesh, and South Africa [2]. Indonesia, with 842,000 cases, is the third country with the highest number of cases of TB worldwide after India and China [2-5].

The compliance with medication intake in patients infected with TB and with other diseases is challenging, leading to multidrug- or rifampicin-resistant (RR) TB (Multidrug resistance [MDR]/RR-TB) [4,5]. Some reasons for this include failure in dose use, indiscipline, and drug interaction with other medicines [6]. Recently, the treatment success rate of patients with TB has decreased from $89.5 \%$ in 2008 to $85.1 \%$ in 2017 [7]. Furthermore, although drug interaction can occur, the combination drug therapy is still effective in treating TB [8]. Problems mentioned earlier are part of the problems observed in treating patients with TB $[2,9,10]$.

Problems related to drug resistance can possibly occur or can potentially become a problem in treatment. Moreover, it can influence quality of life and affect the socioeconomic status of patients. To date, there have been many issues in the management of patients with MDR/RR-TB related to indication, efficacy, safety, and discipline [11,12]. Therefore, pharmacists have an important role in providing drug rationally to patients to tackle and reduce problems [13].
Successful treatment of patients with TB can be achieved by complex treatment with long-term duration. This study aimed to analyze and identify anti-TB drug-related problems at the Tebet Subdistrict Health Center in 2018.

\section{METHODS}

This study used cross-sectional, descriptive, and secondary data analysis from adult prescription medicine from July 2018 to December 2018 at the Tebet Subdistrict Health Center. The study was conducted from February 2019 to July 2019. The study has received a research permit from Unit Pelaksana Pelayanan Terpadu Satu Pintu, Kota Administrasi Jakarta Selatan by number 237/082.61.

The samples of this study were randomly selected from the prescription of patients with TB aged 18-64 years. The diagnosis was coded using the International Classification of Diseases-10 (ICD-10). ICD-10 A15.0 indicates patients with TB confirmed by sputum microscopic test with or without sputum culture, ICD-10 A15.1 indicates patients with TB diagnosed only by sputum culture, ICD-10 A15.2 indicates patients with TB confirmed by histologic examination, and ICD-10 A15.3 indicates patients with TB diagnosed by unpredictable test. Exclusion criteria were incomplete prescriptions, prescription for MDR/RR-TB, pregnant women with TB, patients with HIV, patients with TB, TB with more than one code of ICD-10, and respiratory TB.

Data were analyzed using univariate analysis using Microsoft Excel 2013. Analysis was performed to examine the incidence distribution related to drug problems of patients with TB classified by Cipolle et al. [14]. Furthermore, the data used to analyze the percentage of problems related to medicine and medicine interaction caused from drug therapy 
using online IBM Micromedex Web Access Application and/or Drug Interaction Checker Medscape.

\section{RESULTS}

The total sample was 2023 prescriptions. However, only 483 prescriptions were included in the final analysis. Other prescriptions were excluded because they did not meet the inclusion criteria. Tables 1 and 2 summarize patient characteristics.

The result showed that the TB status in men at $62.41 \%$ was higher than that in women. Based on age, patients with TB were aged $18-<36$ years. Table 2 shows characteristics of patient with TB based on age.

Table 3 shows the description of prescriptions

The problem identification of this study used the classification system from Cipolle et al. [14]. The classification consisted of seven classifications, such as treatment requiring other additional medicines, unnecessary prescription of drugs, overdose, less dose, wrong medicine, unwanted drug reaction, and patient compliance [14]. Table 4 shows the drug problems. Tables 5-9 show the description of drug problems per category.

\section{DISCUSSION}

Population and sample

In this study, the number of male patients with TB was more than that of women. First, this may be due to the patriarchal culture in Indonesia,

Table 1: Characteristics of patient with tuberculosis based on sex

\begin{tabular}{lll}
\hline Sex & Total patients $(\mathbf{n = 1 3 3 )}$ & Percentage \\
\hline Male & 83 & 62.41 \\
Female & 50 & 37.59 \\
\hline
\end{tabular}

Table 2: Characteristics of patients with tuberculosis based on age

\begin{tabular}{lll}
\hline Group of age & Number $(\mathbf{n = 1 3 3})$ & Percentage \\
\hline Group 1 (18-<36 years) & 76 & 57.14 \\
Group 2 (36-<56 years) & 37 & 27.82 \\
Group 3 (56-<65 years) & 20 & 15.04 \\
\hline
\end{tabular}

Table 3: Prescription conditions of patients with TB

\begin{tabular}{lll}
\hline Name of drug & $\begin{array}{l}\text { Frequency } \\
(\mathbf{n = 8 4 3 )}\end{array}$ & Percentage \\
\hline Anti-TB drugs & 529 & 62.75 \\
FDC & 270 & 32.03 \\
Anti-TB drug Category 1 & 232 & 27.52 \\
Anti-TB drug Category 2 & 37 & 4.39 \\
Anti-TB drug category for children & 1 & 0.12 \\
Kombipak & 121 & 14.35 \\
Isoniazid & 44 & 5.22 \\
Rifampicin & 44 & 5.22 \\
Ethambutol & 26 & 3.08 \\
Pyrazinamide & 7 & 0.83 \\
Injection & 138 & 16.37 \\
Streptomycin sulfate & 138 & 16.37 \\
Other than anti-TB drugs & 314 & 37.25 \\
\hline
\end{tabular}

FDC: Fixed-dose combination, TB: Tuberculosis

Table 4: Description of drug problems

\begin{tabular}{lll}
\hline Drug-related problems category & $\begin{array}{l}\text { Recipe sheet } \\
(\mathbf{n = 4 7 9 )}\end{array}$ & $\begin{array}{l}\text { Percentage of } \\
\text { recipe sheet }\end{array}$ \\
\hline With drug-related problems & 383 & 79.30 \\
Without drug-related problems & 96 & 19.70 \\
\hline
\end{tabular}

where men can generally access TB treatment more easily [15]. Second, more men smoke and consume alcohol compared with women. Higher male mobility also increases men's risk for being more exposed to TB-causing bacteria [15]. Women's immunity to TB is higher than in men [16]. Third, the biological microbiological examination of sputum in men is more sensitive than that in women; hence, the detection of TB in men is easier [17].

TB is highly prevalent in the $18-<36$ years of age group. This may be due to the high mobility of the reproductive age, and a dense work environment causes a patient with TB to potentially transmit the disease to his colleagues [15]. In addition, TB can develop potentially more in the reproductive age compared with latent TB [18].

Anti-TB drugs are the most prescribed drugs in TB therapy. This condition is in accordance with the treatment needed, namely, TB therapy with anti-TB drug in the form of fixed dose combination (FDC) and kombipak.

\section{Identification of drug-related problems}

Unnecessary drug therapy

Drug therapy is unnecessary when the patient has no clinical indication. Providing unnecessary therapy can cause resistance, particularly in

Table 5: Description of unnecessary drug therapy

\begin{tabular}{lll}
\hline Drug therapy & Recipe sheet $(\mathbf{n}=\mathbf{8 4 3})$ & Percentage \\
\hline Drug therapy is not needed & 24 & 2.85 \\
Drug therapy is needed & 819 & 97.15 \\
\hline
\end{tabular}

Table 6: Prescription conditions of patients with tuberculosis

\begin{tabular}{lll}
\hline Additional drug therapy & $\begin{array}{l}\text { Recipe sheet } \\
(\mathbf{n = 4 7 9 )}\end{array}$ & $\begin{array}{l}\text { Percentage of } \\
\text { recipe sheet }\end{array}$ \\
\hline Need for additional therapy & 33 & 6,89 \\
No need for additional therapy & 446 & 93,11 \\
\hline
\end{tabular}

Table 7: Ineffective drug prescription

\begin{tabular}{lllll}
\hline $\begin{array}{l}\text { Effective } \\
\text { drug }\end{array}$ & $\begin{array}{l}\text { Recipe } \\
\text { sheet } \\
(\mathbf{n = 8 4 3 )}\end{array}$ & $\begin{array}{l}\text { Percentage } \\
\text { of recipe } \\
\text { sheet }\end{array}$ & $\begin{array}{l}\text { Recipe sheet } \\
(\mathbf{n = 4 7 9 )}\end{array}$ & $\begin{array}{l}\text { Percentage } \\
\text { of recipe }\end{array}$ \\
\hline $\begin{array}{l}\text { Ineffective } \\
\text { drug }\end{array}$ & 13 & 1.54 & 9 & 1.88 \\
Effective drug & 843 & 98,46 & 470 & 98.12 \\
\hline
\end{tabular}

Table 8: Description of the accuracy of tuberculosis therapy doses at the Tebet Subdistrict Health Center

\begin{tabular}{lllll}
\hline Ketepatan dose & $\begin{array}{l}\text { Recipe } \\
\text { sheet } \\
(\mathbf{n = 8 4 3 )}\end{array}$ & $\begin{array}{l}\text { Percentage } \\
\text { of recipe } \\
\text { sheet }\end{array}$ & $\begin{array}{l}\text { Recipe } \\
\text { sheet } \\
(\mathbf{n = 4 7 9 )}\end{array}$ & $\begin{array}{l}\text { Percentage } \\
\text { of recipe }\end{array}$ \\
\hline Accuracy of dosing & 738 & 87.54 & 391 & 81.63 \\
Inappropriate dose & 105 & 12.46 & 88 & 18.37 \\
Overdose & 46 & 5.46 & & \\
Low dose & 59 & 7.00 & & \\
\hline
\end{tabular}

Table 9: Description of potential drug interactions in tuberculosis therapy at the Tebet Subdistrict Health Center

\begin{tabular}{lll}
\hline Interaction & Recipe sheet $(\mathbf{n}=\mathbf{4 7 9 )}$ & Percentage \\
\hline With interaction & 317 & 66.18 \\
No interaction & 162 & 33.82 \\
\hline
\end{tabular}


prescribing antibiotics. In addition, the administration of unnecessary therapy can also cause undesirable effects. The administration of unnecessary drug therapy is due to physicians focusing on the symptoms of the patient, not based on diagnosis. In addition, demands from patients who desire that their symptoms disappear quickly encourage doctors to prescribe medications to treat symptoms.

In TB therapy, side effects are nausea, vomiting, and epigastric pain; increased liver enzyme levels; arthralgia; acne; and cutaneous pruritus or fever [8]. Therefore, in addition to anti-TB drug, additional drugs are also prescribed that are intended to overcome the side effects of TB therapy. Prescribing loratadine, cetirizine, and chlorpheniramine maleate are intended to overcome the side effects of pruritus or itching and rashes. Domperidone, ranitidine, omeprazole, and antacids are prescribed to overcome the side effects of nausea and vomiting.

\section{Required additional therapeutic drugs}

Additional therapeutic drugs are required to prevent the occurrence of a clinical condition or disease and to administer initial therapy for a medical condition. Additional drug therapy required in this study is the provision of anti-TB drug in the form of injection, FDC, or kombipak. Prescriptions considered to require additional therapeutic drugs are those that only relieve TB symptoms but do not treat TB bacterial infections; for example, patients are only prescribed guaifenesin and Vitamin B or are only prescribed salbutamol without being prescribed anti-TB drug in accordance with TB management guidelines. TB therapy without antibiotics can result in more severe infections, recurrence, and resistance if patients only undergo some TB therapy procedures with anti-TB drug.

\section{Ineffective medicine}

Ineffective medicine is when the drug administered does not provide the expected effect suitable for a medical condition. One of the cases found was dexamethasone prescription, wherein the drug was contraindicated for patients with TB. Dexamethasone is an anti-inflammatory agent that works by inhibiting cytokines and decreasing cellular immunity. With decreased immunity, patients with TB become more susceptible to the infectious bacteria. In addition, the administration of dexamethasone can also eliminate the symptoms of TB so the patient feels healed after its administration although the infection still exists if the patient does not undergo therapy with anti-TB drug.

Anti-TB drug for the children category was also prescribed for patients aged 59 years who weigh $41 \mathrm{~kg}$. This case is considered as ineffective drug administration because anti-TB drug for the children category is intended for patients aged $0-14$ years based on the management used at the Tebet Subdistrict Health Center, the National Guidelines for TB Control [19]. For these cases, there are other more effective drug choices, namely, Category 1 or 2 anti-TB drug intended for adult patients weighing at least $30 \mathrm{~kg}$.

\section{Dosage accuracy}

Appropriate dosage is the administration of drugs in accordance with the dose based on the patient's body weight and age, as well as the frequency of administration based on official management. The accuracy of the dose in TB therapy is still a problem because the low dose can result in resistance and lead to failure of therapy, whereas it can result in poisoning in cases of overdose if the dose reaches toxic levels or can even result in death if the dose given reaches the lethal dose.

\section{Drug interaction}

Drug interactions are conditions, wherein the effects of a drug change with the presence of other drugs, herbal medicines, food, drinks, or chemicals in the surrounding environment. The effects of drug interactions can be dangerous if the reaction increases the toxicity of a drug. Reduced drug efficacy is sometimes also as dangerous as increased toxicity.
Most of the interactions that occur in TB management cause hepatotoxicity. However, the use of a combination of interacting drugs cannot be avoided; hence, liver function must be monitored by checking the levels of alanine aminotransferase (ALT) and aspartate aminotransferase to prevent hepatotoxicity. A hepatoprotector, such as curcumin, can also be prescribed to protect the liver from damage. The administration of anti-TB drug can be stopped if the increase in ALT levels exceeds thrice the upper limit of normal (ULN), with an increase in bilirubin levels, or an increase in the ALT levels exceeds 5 times the ULN without increasing the bilirubin level [20].

\section{CONCLUSION}

Patients undergoing TB therapy at the Tebet Subdistrict Health Center from July 2018 to December 2018 are mostly men in the $18-<36$ years of age group. The percentage of unnecessary drug therapy and required additional therapeutic drugs for TB therapy is $2.85 \%$ and $6.89 \%$, respectively. Therefore, prescriptions with writing errors should be immediately revised and updated in the Puskesmas information system so that the data used for further research can actually reflect prescription. The diagnosis in the ICD-10 code should be written in full in accordance with the patient's medical condition to provide the appropriate therapy in accordance with the diagnosis of the physician.

\section{ACKNOWLEDGMENTS}

The authors would like to thank the Tebet Sub-District Health Center for providing permission and data for this study.

\section{CONFLICTS OF INTEREST}

The authors declare that they have no conflicts of interest.

\section{REFERENCES}

1. Wells BG, DiPiro JT, Schwinghammer TL, DiPiro CV. Pharmacotherapy Handbook. $9^{\text {th }}$ ed. Inggris: McGraw-Hill Education Companies; 2015.

2. World Health Organization. Tuberculosis; 2018. Available from: https:// www.who.int/news-room/fact-sheets/detail/tuberculosis.

3. Ministry of Health, Republic of Indonesia. Data and Information Center of the Indonesian Ministry of Health, Tuberculosis. Jakarta: Ministry of Health, Republic of Indonesia; 2018.

4. Nugrahaeni DK, Hadisaputro S, Suwondo A, Dharmana E. The effect of alpha-mangostin in balancing the ratio of cytokines pro-and antiinflammation-gamma (ifn- $\gamma / \mathrm{il}-10$ ) and severity of the disease in mice infected with Mycobacterium tuberculosis multidrug-resistant. Asian J Pharm Clin Res 2016;9:273-7.

5. Pitaloka DA, Sukandar EY. In vitro study of ursolic acid combination first-line antituberculosis drugs against drug-sensitive and drugresistant strains of Mycobacterium tuberculosis. Asian J Pharm Clin Res 2017;10:216-8.

6. Ismail A, Handayany GN, Bakri M. Evaluation of the use of antituberculosis drugs anti-TB drug in pulmonary tuberculosis patients at the Jumpandang Baru Health Center, Makassar. J Farm Fak Kedokteran Ilmu Kesehatan UIN Alauddin 2017;4:194-206.

7. Ministry of Health, Republic of Indonesia. This is the Rational Use of Drugs that must be Understood by the Public. Communication and Community Service Bureau. Jakarta: Ministry of Health, Republic of Indonesia; 2018. Available from: http://www.sehatnegeriku.kemkes. go.id/baca/umum/20180329/3525429/inilah-penggunaan-obatrasional-yang-harus-dipahami-masyarakat.

8. Arbex MA, Varella Mde C, Siqueira HR, Mello FA. Antituberculosis drugs: Drug interactions, adverse effects, and use in special situations. Part 1: First-line drugs. J Bras Pneumol 2010;36:626-40.

9. Muniroh N, Aisah S. Factors related to recovery of pulmonary tuberculosis (TB) in the working area of Mangkang Public Health Center, West Semarang. J Keperawatan Komunitas 2013;1:33-4.

10. Nugraheni K, Malik U. Analysis of the causes of anti-tuberculosis drug resistance [Analisis penyebab resistensi obat anti tuberculosis]. J Kesehatan Masyarakat 2015;11:8-15.

11. Kumar YA, Kumar VR, Ahmad A, Mohanta GP, Manna PK. Pharmacist interventions and pharmaceutical care in an Indian teaching-hospital: A prospective study. Int J Adv Res Biol Sci 2012;1:386-96.

12. Cipolle RJ, Strand LM, Morley PC. Pharmaceutical Care Practice: The Patient-centered Approach to Medication Management. $3^{\text {rd }}$ ed. 
New York: McGraw-Hill Education Companies; 2012

13. Shivaraj G, Muralikhrisna K, Nijeesh CH, Laloo F, Baburaja B, Doddayya H. Study on drug-related problems in tuberculosis patients with comorbidities in a tertiary care teaching hospital. Eur J Pharm Med Res 2017;4:756-67.

14. Cipolle RJ, Strand LM, Morley PC. Pharmaceutical Care Practice. New York: McGraw-Hill; 1998. p. 78-9.

15. Dotulong JF, Sapulete MR, Kandou GD. Relationship between risk factors for age, sex, and occupancy density with the incidence of pulmonary TB disease at Wori regency. J Kedokt Komunitas Tropik 2015;3:57-65.

16. Chinnakali P, Selvaraj K, Thekkur P, Ramasamy G, Thulasingam M, Vasudevan K. Age and sex differences in sputum smear microscopy results for acid fast bacilli in a tertiary care centre, South India. J Respir
Med 2014;2014:1-5.

17. van den Hof S, Najlis CA, Bloss E, Straetemans M. A Systematic Review on the Role of Gender in Tuberculosis Control. United States, Washington, DC: Agency for International Development; 2010

18. Kurnianingsih L, Sudirman I, Utaminingrum W. Identification of Drug Related Problems Treating Tuberculosis in Outpatients at RSUD Kardinah, Tegal in 2009, Thesis. Tegal: Faculty of Pharmacy Universitas Muhammadiyah Purwokerto; 2010.

19. Ministry of Health, Republic of Indonesia. National Guidelines for Tuberculosis Control. Jakarta: Ministry of Health, Republic of Indonesia; 2014.

20. Ningrum VD, Megasari A, Hanifah S. Hepatotoksisitas pada pengobatan tuberkulosis di RSUD Tangerang Indonesia. J Ilmiah Farm 2010;7:49-7. 